\title{
Redução da Turbidez e Escherichia Coli Atcc 25922 em Efluente Sintético de Laticínio Pós-Tratamento com Moringa Oleifera Lam.
}

\author{
Daiane Evelin dos Santos Assunção (I), Fernanda Guimarães \\ Jeronimo (I), Ed Carlo Rosa Paiva (I), Jupyracyara Jandyra de \\ Carvalho Barros (I) \\ (I) UFG/RG - UNIVERSIDADE FEDERAL DE GOIÁS, REGIONAL CATALÃO (Av.: Dr. \\ Lamartine P. Avelar, 1120, Bairro: Setor Universitário; Catalão - GO)
}

\section{Resumo}

Grande volume de efluentes é gerado no setor de laticínios, sendo constante preocupação dessas indústrias o gerenciamento e tratamento desses resíduos antes do descarte no corpo hídrico receptor. Nesse sentido, este estudo objetivou empregar extrato aquoso de sementes de Moringa oleifera Lam. para o tratamento de efluente sintético de laticínio para fins de descarte. $\mathrm{O}$ extrato aquoso em concentrações $0,05 \%, 0,10 \%, 0,15 \%$ e $0,20 \%$ foi aplicado em efluentes elaborados com leite integral reconstituído inoculado com $10^{3}$ células de Escherichia coli ATCC 25922. Foram realizadas três repetições para cada ensaio, sendo realizadas análises de turbidez por nefelometria e contagem do micro-organismo teste a partir da técnica de cultivo em profundidade. A menor concentração $(0,05 \%)$ do extrato demonstrou ser indesejável para esse tratamento, pois conferiu maior turbidez às amostras tratadas, diferindo da concentração $0,15 \%(68,09 \pm 19,31$ NTU). Foi possível evidenciar a redução de $87,9 \%$ da turbidez aos efluentes tratados com extrato a $0,20 \%$ (33,23 $\pm 15,83$ NTU) quanto comparado ao grupo controle $(274,66 \pm 140,54 \mathrm{NTU})$. Semelhante aos testes de turbidez, pós-tratamento com $0,05 \%\left(1,8 \times 10^{3} \pm 2,2 \times 10^{3}\right.$ UFC.100mL $\mathrm{m}^{-1}$ ) não foi evidenciado redução da E. coli ATCC 25922. Possivelmente, a matéria orgânica suspensa e proveniente das sementes de moringa do extrato de $0,05 \%$ foi assimilada pelo micro-organismo teste,

\footnotetext{
Referência:

Daiane Evelin dos Santos Assunção, Fernanda Guimarães Jeronimo, Ed Carlo Rosa Paiva, Jupyracyara Jandyra de Carvalho Barros.Redução da Turbidez e Escherichia Coli Atcc 25922 em Efluente Sintético de Laticínio PósTratamento com Moringa Oleifera Lam.. In: Anais do $12^{\circ}$ Congresso Latinoamericano de Microbiologia e Higiene de Alimentos - MICROAL 2014 [= Blucher Food Science Proceedings, num.1, vol.1]. São Paulo: Editora Blucher, 2014.

DOI 10.5151/foodsci-microal-041
} 
implicando em aumento da densidade populacional. De modo geral, a redução da bactéria foi proporcional ao decréscimo da turbidez, assim o menor escore para esse parâmetro também foi registrado após tratamento com $0,20 \%\left(2,2 \times 10^{2} \pm 3,1 \times 10^{2}\right.$ UFC. $\left.100 \mathrm{~mL}^{-1}\right)$. Para fins de descarte, o extrato a $0,20 \%$ foi adequado para o tratamento do efluente, com possibilidade de emissão desse resíduo em corpo hídrico Classe II e III, conforme classificação do Conselho Nacional do Meio Ambiente CONAMA. A rotina de trabalho empregando a produção mais limpa, aliada ao tratamento de águas residuárias a partir de coagulante natural, tendem a minimizar os impactos negativos desses resíduos no ambiente.

Palavras-Chave: Moringa oleifera, águas residuárias, fins de descarte, resíduos agroindustriais

Agência de Fomento: 